\title{
'A Legal Limited Monarchy': Scottish Constitutionalism in the Union of Crowns, 1603-1707
}

\author{
Karin Bowie, University of Glasgow
}

\begin{abstract}
After the formation of the British composite monarchy in 1603, a distinctive pattern of Scottish constitutionalism emerged in which a desire to maintain the Scottish realm and church encouraged an emphasis on the limitation of the monarch by fundamental law, guaranteed by oaths. The Covenanters attempted to use the National Covenant and the 1651 coronation to force the king to maintain the Presbyterian church as defined by law. Restoration royalists emphasised the untrammelled power of the king, but in the Revolution of 1688-89, the Claim of Right was presented with the oath of accession as a set of conditions designed to re-establish the Scottish realm as a 'legal limited monarchy' with a Presbyterian church. Reforms in 1640-41, 1689-90 and 1703-4 placed statutory constraints on the royal prerogative. The making of the union relied on a reassertion of monarchical sovereignty, though Presbyterian unionists ensured that the new British monarch would be required to swear to uphold the church as established by law.
\end{abstract}

Historiographical cross-currents have produced polarised and fragmented understandings of constitutionalism in seventeenth-century Scotland. ${ }^{1}$ Presbyterian historians of the nineteenth century placed the 1689 Claim of Right in a story of liberalism tracing back through the Covenants and John Knox to the 1320 Declaration of Arbroath. Some went further, building on George Buchanan's idea of an anciently constituted elective monarchy to identify a native tradition of popular sovereignty. ${ }^{2}$ For Victorian unionist-nationalists, the identification of a persistent popular fight for civil and religious liberties allowed a Scottish past of rebellion and resistance to be attached to an Anglo-British parliamentary constitution valorised by Scottish historians from the Enlightenment onwards. ${ }^{3}$ As Colin Kidd has pointed out, Scotland's constitutional history to 1707 became 'a narrative of defective

\footnotetext{
${ }^{1}$ This article is based on a paper delivered at the 2013 Stenton Symposium at the University of Reading. I would like to thank Esther Mijers for inviting me to Reading, my co-panelist Roger Mason for his encouraging and helpful comments on a draft of this article and the JSHS readers for their stimulating and useful suggestions. ${ }^{2}$ C. Kidd and J. Coleman, 'Mythical Scotland' in T. M. Devine and J. Wormald (eds), Oxford Handbook of Modern Scottish History (Oxford, 2014), pp. 72-74; C. Kidd, Union and Unionisms: Political Thought In Scotland 1500-1200 (Cambridge, 2008), 141-43; Neil Forsyth, 'Presbyterian historians and the Scottish invention of British liberty', Records of the Scottish Church History Society 34 (2004), pp. 91-110. These interpretations continue to influence political rhetoric, even as recent scholarship offers a more nuanced view of the legacy of the Declaration of Arbroath. A. Salmond, 'Speech to the Foreign Press Association', 16 Jan. 2013 www.scotland.gov.uk, accessed 20 Dec. 2014; W. E. Bulmer, 'Our future is waiting to be written', Sunday Herald (11 Dec. 2011), pp. 34-36; E. J. Cowan, 'For Freedom Alone': The Declaration of Arbroath, 1320 (East Linton, 2003); R. Mason, 'Beyond the Declaration of Arbroath: kingship, counsel and consent in late medieval and early modern Scotland' in S. Boardman and J. Goodare (eds), Kings, Lords and Men in Scotland and Britain, 1325-1625 (Edinburgh, 2014), pp. 265-282.

${ }^{3}$ Kidd, Union and Unionisms, 139-140, 145-148; C. Kidd, Subverting Scotland's Past: Scottish Whig Historians and the Creation of an Anglo-British Identity, 1689-c.1830 (Cambridge, 1993), pp. 130-144.
} 
state formation'. ${ }^{4}$ At the same time, scholars identified key moments in seventeenth-century English history, including the Levellers' Agreements of the People, the 1649 Revolution and Cromwellian commonwealth and the 1689 Bill of Rights, as precedents for the modern written constitutions of revolutionary France and America. ${ }^{5}$ Contemporaneous Scottish struggles were characterised as second-order religious quarrels. A historian expressed received opinion in 1958 with the comment that 'the origin of the Civil Wars in the 17th century in Scotland is to be traced in differences as to Church government, rather than, as in England, to the limits to be set on the Royal prerogative' ${ }^{6}$ In the later twentieth century, the deconstruction and decline of presbyterian history has tended to reinforce negative views of the seventeenth century, with a recent study labelling it 'the most wretched era of Scottish history'. ${ }^{7}$ Finding few canonised writers and an apparent 'poverty' of political thought, intellectual historians have found more of interest in the earlier writings of George Buchanan and James VI or the later work of Andrew Fletcher of Saltoun. ${ }^{8}$ Though Samuel Rutherford and the marquis of Argyll have attracted recent attention, later Covenanting political thought tends to be seen as a disappointment to Buchanan's legacy. ${ }^{9}$

More generous perspectives, however, have emerged from a number of different directions.

The Scottish Parliament Project at St. Andrews University has produced a three-volume history of the

\footnotetext{
${ }^{4}$ Kidd, Union and Unionisms, 148.

${ }^{5}$ E. S. Morgan, The Invention of the People: The Rise of Popular Sovereignty in England and America (New York and London, 1989); A. Lyon, Constitutional History of the United Kingdom (London, 2003).

6 J. I. Smith, 'The Transition to the Modern Law 1532-1660' in An Introduction to Scottish Legal History (Alva, 1958), p. 31.

${ }^{7}$ D. Stevenson, 'Twilight before night or darkness before dawn? Interpreting seventeenth-century Scotland', in R. Mitchison (ed.), Why Scottish History Matters (Edinburgh, 1991), pp. 37-47; M. Fry, The Union: England, Scotland and the Treaty of 1707 (Edinburgh, 2006), p. 310.

${ }^{8}$ B. Lenman, 'The poverty of political theory in the Scottish revolution of 1688-1690' in L. G. Schwoerer (ed.), The Revolution of 1688-89: Changing Perspectives (Cambridge, 1992), pp. 244-59; Q. Skinner, Foundations of Modern Political Thought, vol. 2 (Cambridge, 1978), pp. 113-134; J. H. Burns, The True Law of Kingship: Concepts of Monarchy in Early Modern Scotland (Oxford, 1996); R. A. Mason, 'George Buchanan, James VI and the presbyterians' in R. A. Mason (ed.), Scots and Britons: Scottish Political Thought and the Union of 1603 (Cambridge, 1994), pp. 112-137; R. A. Mason, 'James VI, George Buchanan, and "The True Lawe of Free Monarchies"' in R. A. Mason (ed.), Kingship and the Commonweal (East Linton, 1998), pp. 215-41; R. Mason and C. Erskine (eds), George Buchanan: Political Thought in Early Modern Britain and Europe (Farnham, 2012); A. Fletcher, Political Works, ed. J. Robertson (Cambridge, 1997).

${ }^{9}$ J. Coffey, Politics, Religion and the British Revolutions: The Mind of Samuel Rutherford (Cambridge, 1997); E. J. Cowan, 'The political ideas of a covenanting leader: Archibald Campbell, marquis of Argyll 1607-1661' in Mason (ed.), Scots and Britons, 241-261; A. I. Macinnes, The British Confederate: Archibald Campbell, Marquis of Argyll, 1607-1661 (Edinburgh, 2011); Mason and Erskine (eds), George Buchanan, part III.
} 
Scottish parliament and a digital record of parliamentary acts to $1707 .{ }^{10}$ This work and other analyses of early modern government and parliament by Julian Goodare, Alan R. Macdonald, John Young,

Gillian MacIntosh and Alastair Mann have begun to correct a longstanding portrayal of the Scottish parliament as, in Keith Brown's words, a 'peripheral, unsophisticated, corrupt and subservient body'. ${ }^{11}$ This work has identified the formation of a Court-Country axis which facilitated constitutional debate and has highlighted forms of parliamentary constitutionalism from the Covenanters to the Union. ${ }^{12}$ Studies of Scottish national identity after 1603 have emphasised the significance of the Scottish parliament as a marker of national distinctiveness and sovereignty. ${ }^{13}$ In a British context, a multiple-kingdoms perspective has helped to direct attention to Scottish constitutionalism in the work of Alan Macinnes and Ted Cowan on the Wars of the Three Kingdoms and Tim Harris on the 1688-89 Revolution. ${ }^{14}$ This has highlighted Scottish precedents for English constitutional reforms, though an emphasis on British parallels risks losing sight of the distinctive

\footnotetext{
${ }^{10}$ K. Brown, R. Tanner and A. Macdonald (eds), History of the Scottish Parliament, 3 vols (Edinburgh, 20042010); K. Brown (gen. ed.), Records of the Parliaments of Scotland to 1707 [hereafter RPS] (St. Andrews, 20072014), www.rps.ac.uk .

${ }^{11}$ K. M. Brown, 'Scottish identity in the seventeenth century' in B. Bradshaw and P. Roberts (eds), British Consciousness and Identity: The Making of Britain, 1533-1707 (Cambridge, 1998), pp. 236-258, at p. 239; J. Goodare, The Government of Scotland, 1560-1625 (Oxford, 2004); J. Goodare, State and Society in Early Modern Scotland (Oxford, 1999); A. R. Macdonald, 'Consultation and Consent under James VI', Historical Journal 54, 2 (June 2011), pp. 287-306; A. R. Macdonald, 'Voting in the Scottish Parliament before 1639', Parliaments, Estates and Representation 30:2 (2010), pp. 145-161; Macdonald, 'Deliberative processes'; J. R. Young, The Scottish Parliament 1639-1661: A Political and Constitutional Analysis (Edinburgh, 1996); G. MacIntosh, The Scottish Parliament under Charles II, 1660-1685 (Edinburgh, 2007); A. Mann, 'Inglorious Revolution: Administrative Muddle and Constitutional Change in the Scottish Parliament of William and Mary', Parliamentary History 22, 2 (2003), pp. 121-44.

${ }^{12}$ J. Goodare, 'The Scottish Parliament of 1621', Historical Journal 38,1 (March 1995), pp. 29-51; J. R. Young, 'The Scottish parliament and the covenanting heritage of constitutional reform' in A. I. Macinnes and J. Ohlmeyer (eds), The Stuart Kingdoms in the Seventeenth Century: Awkward Neighbours (Dublin, 2002), pp. $226-250$

${ }^{13}$ C. Jackson, 'Conceptions of Nationhood in the Anglo-Scottish Union Debates of 1707', Scottish Historical Review 87, suppl. (2008), pp. 70-71; Brown, 'Scottish identity', pp. 239-40; J. R. Young, 'The Scottish parliament and national identity from the Union of Crowns to the Union of Parliaments, 1603-1707' in D. Broun, R. Finlay, and M. Lynch, Image and Identity: The Making and Re-making of Scotland through the Ages (Edinburgh, 1998), pp. 105-42.

${ }^{14}$ Macinnes, British Confederate; A. I. Macinnes, The British Revolution, 1629-1660 (Basingstoke, 2005), pp. 68-89; A. I. Macinnes, Charles I and the Making of the Covenanting Movement (Edinburgh, 1991); A.I. Macinnes, 'The Scottish constitution 1638-1651: The rise and fall of oligarchic centralism' in J. Morrill (ed.), The Scottish National Covenant in its British Context (Edinburgh, 1990), pp. 106-33; E. J. Cowan, 'The making of the National Covenant', in Morrill (ed.), Scottish National Covenant, pp. 68-89; T. Harris, 'The People, the Law, and the Constitution in Scotland and England: a Comparative Approach to the Glorious Revolution', Journal of British Studies 38 (January 1999), pp. 28-58; T. Harris, Revolution: The Great Crisis of the British Monarchy, 1685-1720 (London, 2006).
} 
nature of Scottish constitutionalism. ${ }^{15}$ Lastly, the tercentenary of the 1707 union has stimulated fresh research on the impact of the Union of Crowns, supplemented by comparative work on early modern composite monarchies. ${ }^{16}$

Concurrent with a rediscovery of Scottish constitutional history, fresh contextualisation has been brought to English constitutionalism, rescuing it from teleological readings as the well-spring of modern constitutions. ${ }^{17}$ This work has emphasised the importance of religious motives in shaping constitutionalist thinking, as in Alan Cromartie's account of the twin influences of late medieval legal thought and the long Reformation on English concepts of the constitution. ${ }^{18}$ Methodologically, researchers have become less likely to treat sources such as the Agreements of the People as 'pieces of abstract political thought'. Instead, Jason Peacey and others have seen them as 'political blueprints' and 'adjuncts to petitioning, lobbying and rallying', deeply embedded in events. ${ }^{19}$

Though scholars have begun to recover the vitality of Scottish constitutional thinking in the Union of Crowns century, perspectives remain fragmented across studies focusing on reigns and events. ${ }^{20}$ This paper will trace lines of continuity in Scottish constitutionalism across the Union of Crowns period as expressed in statutes, records, pamphlets and speeches produced to meet the exigencies of events. Though Sharon Adams and Julian Goodare have warned against an overemphasis on 1603 as a milestone in Scottish history, they confirm that the regal union had a

\footnotetext{
${ }^{15}$ Macdonald, 'Deliberative processes', 23; Goodare, State and Society, 4; J. R. Young, 'The Scottish parliament and the Covenanting Revolution: the emergence of a Scottish Commons' in J. R. Young (ed.), Celtic Dimensions of the British Civil Wars (Edinburgh, 1997), pp. 164-184.

${ }^{16}$ T. C. Smout (ed.), Anglo-Scottish Relations from 1603 to 1900 (Oxford, 2005), pp. 13-125; A. I. Macinnes, Union and Empire: The Making of the United Kingdom in 1707 (Cambridge, 2007), part II-III; J. Robertson, 'Empire and Union: Two Concepts of the Early Modern European Political Order', in J. Robertson (ed.), A Union for Empire: Political Thought and the British Union of 1707 (Cambridge, 1995), pp. 3-36; J. Arrieta and J.H. Elliot (eds), Forms of Union: The British and Spanish Monarchies in the Seventeenth and Eighteenth Centuries (Donostia, 2009).

${ }^{17}$ This includes, for example, A. Hessayon and D. Finnegan (eds), Varieties of Seventeenth-and EighteenthCentury English Radicalism in Context (Farnham, 2011); P. Baker and E. Vernon (eds), The Agreements of the People, the Levellers and the Constitutional Crisis of the English Revolution (Basingstoke, 2012). For a review of civil war historiography, see G. Burgess, 'Introduction: religion and the historiography of the English Civil War' in C. W. A. Prior and G. Burgess (eds), England's Wars of Religion, Revisited (Farnham, 2011), pp. 1-26. Interest in claiming modernity continues, e.g. S. Pincus, 1688: The First Modern Revolution (London, 2009).

${ }^{18}$ A. Cromartie, The Constitutionalist Revolution: An Essay on the History of England, 1450-1642 (Cambridge, 2006).

${ }^{19}$ Jason Peacey, 'The people of the Agreements: the Levellers, civil war radicalism and political participation' in Baker and Vernon (eds), Agreements of the People, p. 50.

${ }^{20}$ Longer term perspectives can be found in K. M. Brown, Kingdom or Province? Scotland and the Regal Union, 1603-1715 (Basingstoke, 1992); G. H. MacIntosh and R. J. Tanner, 'Balancing acts: the Crown and Parliament' in K. M. Brown and A. R. Macdonald (eds), Parliament in Context, 1235-1707 (Edinburgh, 2010), pp. 1-30; and, as noted above, Young, 'Scottish parliament and the covenanting heritage'.
} 
significant effect on the government of Scotland. ${ }^{21}$ Constitutionalist responses to the formation of the British composite monarchy can be identified in the development of practical ideas and actions designed to set meaningful limits on the Scottish monarchs in London. Over time, deliberate attempts to impose constraints on the monarch produced a distinctive - though not universally endorsedimage of Scotland as a 'legal limited monarchy'. This term, taken from the 1689 Claim of Right, represents neither a pale shadow nor an anachronistic moment of modernity, but a form of early modern constitutionalism that shaped both Scottish and British history.

'Constitutionalism' in this study indicates attempts to define a Scottish realm in which the king was constrained by law in principle, and in practice by specific, identified laws. As Ken MacMillan has pointed out in an Atlantic context, in this era polities were understood to be regulated by aggregations of 'laws, customs, policies, and conventions' and there could be significant debate over the precise constitution of the realm. ${ }^{22}$ In moments of conflict between 1603 and 1707, declarations and statutes sought to force the Scottish king to respect particular laws. The coronation oath and covenant oaths were used in ways designed to bind the king and nation in a contractual relationship with a mutual obligation to uphold specific laws. This might be termed 'confessional constitutionalism' in recognition of the importance placed on preserving a particular vision of the Scottish church as expressed in particular laws and national confessional oaths, especially in the National Covenant of 1638 . While this paper will focus on activity that could be labelled 'presbyterian', or at least anti-episcopal, political thought with royalist and episcopalian sympathies also will be explored. Rooted in Jacobean absolutist theory and evolving in tandem with its presbyterian counterpart, royalist political thought has attracted recent scholarly attention but like presbyterian political thought, its analysis remains underdeveloped across the Union of Crowns period. $^{23}$

\footnotetext{
${ }^{21}$ S. Adams and J. Goodare, 'Scotland and its seventeenth-century revolutions' in S. Adams and J. Goodare (eds), Scotland in the Age of Two Revolutions (Woodbridge, 2014), pp. 2-4.

${ }^{22} \mathrm{~K}$. MacMillan, The Atlantic Imperial Constitution: Center and Periphery in the English Atlantic World (Basingstoke, 2011), p. 2. On the transition to a written constitution in the American context, see M. Warner, The Letters of the Republic: Publication and the Public Sphere in Eighteenth-Century America (Cambridge, MA, 1990), pp. 96-117.

${ }^{23}$ Kidd and Coleman, 'Mythical Scotland', p. 66; C. Jackson, Restoration Scotland, 1660-1690: Royalist

Politics, Religion and Ideas (Woodbridge, 2013); J. D. Ford, 'Lex, rex iusto posita: Samuel Rutherford on the
} 
George Buchanan's Dialogue of 1578 asserted that the law was above the king while his 1582 History attempted to show that the Scottish realm had been founded in ancient times on a principle of elective monarchy by which a king could be removed if he did not respect the law. ${ }^{24}$ The idea that the king was subject to the law, however, did not offer much help when, by the early seventeenth century, increasingly effective management of parliament made it possible for the king to pass new laws to suit his purposes. ${ }^{25}$ As Arthur Williamson has observed, 'a particularly compelling interest in maintaining the law' was evinced by supporters of the 'Golden Act' of 1592 which ratified presbyterian church government. ${ }^{26}$ Though ancient constitutionalism appealed not just to Buchanan but also French and English theorists of the later sixteenth century and, as will be seen, was reclaimed by Scottish royalists in the seventeenth century, relatively recent parliamentary law provided a more usable past for those attempting to limit the actions of the monarch after 1603 .

This law-oriented strategy relied on the rising stature of parliamentary legislation. ${ }^{27}$ J.H. Burns has shown that the late medieval Scottish parliament was accepted as the most appropriate means of promoting good governance through acts passed by the king with the consent of the three estates. ${ }^{28}$ In Sir David Lindsay's mid-sixteenth century play, Ane Satyre of the Thrie Estates, the restoration of the commonweal relied on legislation authorised by the king and a reinvigorated parliament. ${ }^{29}$ Parliamentary acts were accepted as legitimate in principle, though contemporaries recognised that the estates could be controlled by factions or monarchs. ${ }^{30}$ Historians agree that by 1603, parliamentary statute was understood as the supreme form of law in Scotland, above both civil and case law. ${ }^{31}$ The crown encouraged this view by authorising the publication of acts of parliament in Scots from 1566 and requiring all heritors to purchase Sir John Skene's 1597 collection of statute

origins of government' in Mason (ed.), Scots and Britons, pp. 262-290; D. Allan, Philosophy and Politics in Later Stuart Scotland: Neo-Stoicism, Culture and Ideology in an Age of Crisis, 1540-1690 (East Linton, 2000).

${ }^{24}$ George Buchanan, A Dialogue on the Law of Kingship among the Scots, M. S. Smith and R. A. Mason (trans. and ed.), (Edinburgh, 2006); R. A. Mason, 'People power? George Buchanan on resistance and the common man' in R. von Fredeberg (ed.), Widerstandsrecht in der fruhen Neuzeit (Berlin, 2001), pp. 163-81.

${ }^{25}$ MacIntosh and Tanner, 'Balancing acts', pp. 19-20.

${ }^{26}$ Arthur Williamson, Scottish National Consciousness in the Age of James VI (Edinburgh, 1979), p. 69.

${ }^{27}$ Mark Godfrey, 'Parliament and the Law' in Brown and Macdonald (eds), Parliament in Context, pp. 176, $178-80$.

${ }^{28}$ Burns, True Law, pp. 107, 110.

${ }^{29}$ Sir David Lindsay, Ane Satyre of the Thrie Estaitis, ed. R. Lyall (Edinburgh, 1998).

${ }^{30}$ J. H. Burns, 'Political ideas and parliament' in Brown and Macdonald (eds), Parliament in Context, p. 218.

${ }^{31}$ Levack, 'Law, sovereignty and the union', p. 218; Goodare, Government of Scotland, pp. 70-86; MacIntosh and Tanner, 'Balancing acts', pp. 4-16. 
law. ${ }^{32}$ Roger Mason has shown how these published collections contributed to a contemporary sense of the distinctiveness of the Scottish realm and its laws. ${ }^{33}$

This supports Levack's identification of 'a developing Scottish concept of fundamental law', rooted not in the common law as in England but in parliamentary statutes defining and regulating the institutions of the realm and the succession to the crown. ${ }^{34}$ This was more similar to the late sixteenthcentury French sense of lois fundamentales, used in relation to contractual monarchy and monarchical succession. ${ }^{35}$ The currency of fundamental law can be seen in 1604 with the discussion of proposals to formalise a 'constant and friendly conjunction' between the English and Scottish kingdoms. ${ }^{36}$ Both English and Scottish legislation for union talks deployed the language of fundamental law in delineating limits on the negotiations. ${ }^{37}$ Acknowledging concerns about a formal union, the preamble to the Scottish act declared that the king did not intend to 'prejudice or hurt the fundamental laws, ancient privileges, offices and liberties of this kingdom' ${ }^{38}$ The unionist Scottish lawyer John Russell employed the language of fundamental law in a pamphlet reassuring the Scots that the "happie and blissed unioun' would not alter the 'ancienne estait, lawis, statutis and auld constitutiounes' of Scotland. ${ }^{39}$ Parliament's 'Commission for the Union' of 11 July 1604 invoked fundamental laws to restrict union negotiations, authorising representatives to agree terms only insofar as these did not damage 'in any way any fundamental laws, ancient privileges, offices, rights, dignities and liberties of

\footnotetext{
${ }^{32}$ The actis and constitutiounis of the realme of Scotland maid in Parliamentis (Edinburgh, 1566); Sir John Skene (ed.), The lawes and actes of Parliament (Edinburgh, 1597); Regiam majestatem: the auld lawes and constitutions of Scotland ... translated out of Latine in Scottish language, to the use and knawledge of all the subjects within this realme (Edinburgh, 1609); D. Masson (ed.), Register of the Privy Council of Scotland, series 1, vol. 5 (1592-1599) (Edinburgh, 1882), p. 463.

${ }^{33}$ R. A. Mason, 'Certeine Matters Concerning the Realme of Scotland: George Buchanan and Scottish SelfFashioning at the Union of the Crowns', Scottish Historical Review 92, part 1, 233 (April 2013), pp. 38-65.

${ }^{34}$ B. Levack, 'Law, sovereignty and the union' in Mason (ed.), Scots and Britons, p. 223.

${ }^{35}$ J. Ford, Law and Opinion in Scotland During the Seventeenth Century (Oxford, 2007), p. 442.

${ }^{36}$ RPS 1604/4/20, 'Commission for the Union', 11 July 1604; B. Galloway, The Union of England and Scotland (Edinburgh, 1986).

${ }^{37}$ RPS 1604/4/20, 'Commission for the Union'; 'An act authorising certain commissioners of the realm of England to treat with commissioners of Scotland, for the weal of both kingdoms', G. W. Prothero (ed.), Select Statutes and Other Constitutional Documents Illustrative of the Reigns of Elizabeth and James I (Oxford, 1912), pp. 251-2. The terminology was used in a letter from James VI to the English parliament in April 1604 and subsequently appeared in the parliamentary acts. Ford, Law and Opinion, pp. 465-66.

${ }^{38}$ See also D. Masson (ed.), Register of the Privy Council of Scotland, series 1, vol. 7 (1604-1607) (Edinburgh, 1885), pp. 457-9.

${ }^{39}$ J. Russell, 'A treatise of the happie and blissed unioun', in B. R. Galloway and B. P. Levack (eds), The Jacobean Union: Six Tracts of 1604 (Edinburgh, 1985), pp. 85, 90, 125-7.
} 
this kingdom' ${ }^{40}$ The estates also placed a more specific emphasis on recent statutes with an additional act confirming standing law in favour of the reformed church and barring negotiators from doing anything that 'in any manner of way may be hurtful or prejudicial to the religion presently professed in Scotland, acts of parliament made in favour of the same religion and discipline established and observed for maintenance and preservation thereof ${ }^{41}$ Appalled that Scotland's parliamentary prelates had voted on these matters without the advice of a General Assembly, in July 1604 three ministers protested in Aberdeen against the failure of the king to call an Assembly to discuss the proposed union. They emphasised recent law and practice in justifying regular meetings of the Assembly by 'the Word of God, constitutiouns, and continuall custome of our kirk, [and] the laws of the realm'. ${ }^{42}$ These responses reflected a contemporary sense of an ancient Scottish realm constituted in fundamental law and a reformed church constituted in recent parliamentary law and practice.

Though the union talks came to little, the formation of the British composite monarchy changed the nature of Scottish governance by encouraging an increase in royal management of national assemblies and an expansion in the stature of bishops as administrative officers in church and state. ${ }^{43}$ While both trends had appeared before 1603, the departure of the monarch for London produced what Alan Macdonald has identified as a cumulatively catastrophic reduction in consultation over the first three decades of the regal union. ${ }^{44}$ Moreover, though scholars have debated how far James VI intended to conform the Scottish presbyterian church to an English episcopalian model, many in Scotland perceived the king's advancement of bishops as a remodelling of the Scottish church on English lines. ${ }^{45}$ For the cleric Alexander Hume, those who supported the rise of

\footnotetext{
${ }^{40}$ RPS 1604/4/20, 'Commission for the Union'.

${ }^{41} R P S$ 1604/4/21, 'Act in favour of the kirk', 11 July 1604.

${ }^{42}$ D. Calderwood, History of the Kirk of Scotland, 8 vols, ed. T. Thomson (Edinburgh, 1845), vol. 6, pp. $267-8$.

J. Row, The History of the Kirk of Scotland (Edinburgh, 1842), pp. 224-5.

${ }^{43}$ V. T. Wells, 'Constitutional conflict after the Union of Crowns: contention and continuity in the parliaments of 1612 and 1621' in K. M. Brown and A. J. Mann (eds), Parliaments and Politics in Scotland, 1567-1707 (Edinburgh, 2005), pp. 82-100; A. R. MacDonald, The Jacobean Kirk, 1567-1625: Sovereignty, Polity and Liturgy (Aldershot, 1998), pp.121-170; S. Tuckett, 'The Scottish bishops in government, 1625-1638' in Scotland in the Age of Two Revolutions, pp. 59-78.

${ }^{44}$ Macdonald, 'Consultation and consent'.

${ }^{45}$ On these debates, see J. Wormald, 'The headaches of monarchy: kingship and the Kirk in the early seventeenth century' in J. Goodare and A. MacDonald (eds), Sixteenth-Century Scotland (Leiden, 2008), pp. 365-393.
} 
episcopalian rule were conforming to 'the Disciplin of our nychtbour countrey of England' ${ }^{46}$ This identification of royal management in church and state with English modes of church government sharpened a desire to delineate a distinct Scottish constitution within the regal union.

As James VI rebuilt the Scottish episcopate, oppositional clergy continued to make public protestations asserting a statutory and customary basis for regular meetings of the General Assembly. ${ }^{47}$ A more aggressive campaign of constitutionalist resistance was triggered in 1618 when a set of controversial articles was pushed through a divided General Assembly in Perth. These introduced significant changes in the sacramental practices of the Scottish reformed church, including a requirement to kneel at communion. The presbyterian cleric David Calderwood characterised the articles as illegitimate because they had not been passed by a 'free and formall Assemblie'. ${ }^{48}$ Though parliament ratified the Articles in 1621, this was deemed invalid because parliamentary debate had been restricted and the crown and its bishops had secured undue control over the Lords of the Articles, a committee for preparing legislation. ${ }^{49}$ A group of clerics made an unusually public protest against the ratification by posting a formal protestation on the mercat cross and kirk doors in Edinburgh. This demanded that parliament defend the church as established by law and reject the 'corruption' represented by the Perth Assembly. ${ }^{50}$ The protestation underpinned a subsequent campaign of civil disobedience to kneeling at communion, requiring in turn a significant extension of episcopal control over both clergy and laity through the Court of High Commission, revived by James VI in $1610 .^{51}$

Accumulated discomfort with royal control of the General Assembly and parliament fuelled a constitutionalist explosion generated by the promulgation of a new prayer book by royal proclamation in $1637 .{ }^{52}$ Protesters advanced constitutionalist arguments against the king's apparent disregard for

\footnotetext{
${ }^{46}$ Hume, 'Ane afold admonitioun', p. 570.

${ }^{47}$ Calderwood, History, vol. 6, pp. 485-539, vol. 7, pp. 250-6; Row, History, pp. 307-311.

${ }^{48}$ D. Calderwood, Perth Assembly ([Leiden], 1619), quote at sig. A3r.

${ }^{49}$ Goodare, 'Scottish Parliament of 1621'.

${ }^{50}$ Calderwood, History, vol. 7, pp. 485-7, 506-7.

${ }^{51}$ L. Stewart, "Brothers in treuth": propaganda, public opinion and the Perth Article debate' in R. Houlbrooke (ed.), James VI and I: Ideas, Authority and Government (Aldershot, 2006), pp. 151-168; Macdonald, Jacobean Kirk, p. 144.

${ }^{52}$ Macinnes, Charles I; Wells, 'Constitutional conflict' and J. R. Young, 'Charles I and the 1633 Parliament' in Brown and Mann (eds), Parliament and Politics in Scotland, 1567-1707; J. Goodare, 'The Scottish Convention of Estates of 1630', Scottish Historical Review 93, part 2, 237 (Oct. 2014), pp. 217-239.
} 
standing law. It was claimed that the Scottish 'forme of publik worship' had been 'receaved be [by] the whol kingdome, ratified be estaits of parliament, and still since put in practice' and had been 'never yet abolished be any act of generall assemblie' or 'king and estaits in parliament'. ${ }^{53}$ This claim simplified the complicated history of the reformed liturgy in Scotland but indicates what was believed at the time by opponents of the new prayer book. ${ }^{54}$ From September 1637, an extensive petitioning campaign objected to the new liturgy as unlawful and unconstitutional as well as theologically suspect. A petition from the presbytery of Kirkcudbright to the Privy Council was typical in arguing that the prayer book had been imposed "contrair to the ordour of law appointit in this realme for establisheing of maters ecclesiastick. ${ }^{55}$ In order to support the contention that liturgical changes were invalid without the consent of the church and the estates of Scotland through their assemblies, petitions spoke in the name of constituent units of the church and estates. ${ }^{56}$ In the parliamentary burgh and parish of Cupar, for example, the 'provest, baillies and counsall of Cupar and elderis of the kirk thairof' petitioned 'in name of the communitie and parochinaris of the samyn'. ${ }^{57}$

Intransigence on the part of Charles I led to an escalation in resistance with the 1638 National Covenant. Believing that the king's policies threatened to 'betray the lawfull liberties of the kingdome' and 'forsake the way of true religione establisched by law', the organisers aimed to renew

\footnotetext{
${ }^{53}$ J. M. Henderson, 'An "Advertisement” about the Service Book, 1637', Scottish Historical Review 23 (1925/1926), p. 204.

${ }^{54}$ The Scots did not have an indigenous liturgy but the 1560 Confession of Faith defined the practice of the kirk in terms of its preaching, discipline and 'right administration' of the sacraments of baptism and communion. The Genevan Book of Common Order was acknowledged as a liturgical guide, with some elaboration, in the 1560 First Book of Discipline. This book was reviewed by a convention of estates and the reformers understood it to have been approved by an act of the privy council, though it was not ratified by parliament. The General Assembly in 1562 agreed to use the Genevan book for the sacraments and in 1564 added its use for 'Prayers' and ordered all parish clergy to have a copy of an authorised psalm book containing the Genevan forms. The Confession of Faith was ratified in parliament in 1560 and the authority of the church as defined by its preaching, discipline and administration of sacraments was ratified again in 1579 along with an order that all substantial householders also possess a psalm book. G. Donaldson, 'Reformation to Covenant' in D. Forrester and D. Murray (eds), Studies in the History of Worship in Scotland (Edinburgh, 1984), pp. 35-36; J. K. Cameron (ed.), The First Book of Discipline (Glasgow and Edinburgh, 2005), pp. 10-13, 90-93; T. Thomson (ed.), Acts and Proceedings of the Assemblies of the Kirk of Scotland, 3 vols. (Edinburgh, 1839), vol. 1, p. 30, 54; RPS A1567/12/3, 'The Confession of Faith', [Dec. 1567]; 1579/10/21, 'Concerning the true and holy kirk and of those declared not to be of the same', 1579/10/22, 'Concerning the jurisdiction of the kirk', 1579/10/25, 'That householders have bibles and psalm books', 10 Nov. 1579. I am grateful to my colleague Scott Spurlock for his advice on this point.

${ }^{55}$ P. Hume Brown (ed.), Register of the Privy Council, second series, vol. 6 (1635-37) (Edinburgh, 1905), p. 710.

${ }_{57}^{56}$ Ibid., pp. 699-716.

${ }^{57}$ Ibid., p. 700.
} 
the 1581 Negative Confession with 'additions' as required by the 'corruptiones of this tyme' ${ }^{58}$ The anti-Catholic Negative Confession had been sworn by the king and his household and then circulated for wider subscription. ${ }^{59}$ The confession and its renewal in 1638 drew on the Scottish practice of banding and reflected an increasingly common post-Reformation European practice of mass oaths developed from medieval oaths of fealty and commune citizenship..$^{60}$ The 1581 oath had emphasised statute law and lawful practice in asserting that the 1560 Scottish confession of faith had been 'established and publicly confirmed by sundry acts of parliaments, and now of a long time has been openly professed by the king's majesty and whole body of this realm'. It required swearers to 'continue in the obedience of the doctrine and discipline of this kyrk' and 'defend the same'. ${ }^{61}$ By 1585, Arthur Williamson observes, the Negative Confession was being compared to the Israelites' covenant with God. ${ }^{62}$ In 1590 , local commissioners were appointed for a national renewal of the confessional oath with an updated band enjoining all subjects to defend the true religion. ${ }^{63}$ By the early seventeenth century, the oath was seen as a fence against creeping episcopalianism. Alexander Hume had the 1581 oath in mind when he stated in 1609 that the 'forme of Discipline' of the kirk, its presbyterian governance by a hierarchy of church courts, had been 'affirmed to be agreeable with the Word of God', 'subscryvit be many notable preacheris and professoris of the Reformed Religioun' and 'ratefeit in Parliament by the Prince and the whole Estatis of the kingdome: promesing by a solemn othe to remane constant thairat, and to defend it to thair lvyes end. ${ }^{64}$ The binding nature of the

\footnotetext{
${ }^{58}$ J. Leslie, $6^{\text {th }}$ earl of Rothes, A Relation of Proceedings Concerning the Affairs of the Kirk of Scotland, from August 1637 to July 1638 (Edinburgh, 1830), pp. 68-70.

${ }^{59}$ Williamson, Scottish National Consciousness, p. 68; G. Donaldson (ed.), Scottish Historical Documents (Glasgow, 2d edition, 1999), pp. 150-53.

${ }^{60}$ J. Dawson, 'Bonding, religious allegiance and covenanting' in Boardman and Goodare (eds), Kings, Lords and Men, pp. 155-172; E. Vallance, 'Oaths, covenants, associations and the origins of the Agreements of the People: the road to and from Putney' in Baker and Vernon (eds), The Agreements of the People, pp. 29-30; M. Jones, Conscience and Allegiance in Seventeenth-Century England: The Political Significance of Oaths and Engagements (Rochester, 1999).

${ }^{61}$ Donaldson (ed.), Scottish Historical Documents, p. 151.

${ }^{62}$ Williamson, Scottish National Consciousness, 67-68, 73

${ }^{63}$ D. Masson (ed.), Register of the Privy Council, series 1, vol. 4 (1585-1592), (Edinburgh, 1881), pp. 463-67; Calderwood, History, vol. 5, pp. 45-52.

${ }^{64}$ Hume, 'Ane afold admonitioun', pp. 569-70, 573. See also a similar statement by David Black in 1596 in Calderwood, History, vol. 5, p. 458.
} 
1581 oath was reiterated by Calderwood in his printed attacks on the Articles of Perth and in the 1621 protestation against the ratification of the Articles. ${ }^{65}$

The 1638 covenant oath elaborated the 1581 promise to maintain the reformed church by including a long list of statutes defining reformed doctrine and presbyterian discipline. It required swearers to disregard the king's recent innovations until they could be 'tryed and allowed in frie assemblies and in parliamentes'. Swearers were to defend the authority of the king insofar as this was consistent with 'the defence and preservatione of the foirsaid true religioun, liberties and lawes of the kingdome', implying a condition on the oaths of allegiance sworn at Scottish coronations. ${ }^{66}$ The Covenant also used an act of 1584 requiring subjects to maintain the authority of parliaments to suggest that swearers had a legal obligation to uphold acts in favour of the presbyterian church; and it renewed the demand of the 1604 Union Commission for the preservation of the fundamental laws of the realm. ${ }^{67}$ In response to concerns about the legality of the covenant, its organisers defined it as 'a publict covenant of the collectiue body of the kingdom with God for God and the King' and therefore not subject to an act of 1425 against leagues and bonds between the lieges; and, at any rate, subjects had an overriding duty to maintain the constitutional laws and liberties of the kingdom. ${ }^{68}$ In reply, royalists argued that the Covenant presented an unauthorised interpretation of the 1581 confession and included an illegitimate constraint on loyalty to the king. ${ }^{69}$

The Covenanters used their control of Parliament in 1640 and 1641 to bolster their constitutionalist approach with new acts placing explicit statutory limits on royal power. These included acts excluding the estate of bishops from the Scottish parliament, a triennial act requiring parliament to meet at least every three years even if not summoned by the monarch, an act reducing

\footnotetext{
${ }^{65}$ J. Ford, 'The Lawful Bonds of Scottish Society: the Five Articles of Perth, the Negative Confession and the National Covenant', Historical Journal 37, 1 (1994), pp. 48-54; Calderwood, History, vol. 7, p. 486.

${ }^{66} \operatorname{RPS} 1640 / 6 / 36$, 'The act of the general assembly ordaining by ecclesiastical authority the subscription of the faith and covenant'. For the medieval oaths, see R. J. Lyall, 'The medieval Scottish coronation service: some seventeenth-century evidence', Innes Review 28 (Spring 1977), 9-10. For the oaths sworn at the 1633 coronation of Charles I, see The ceremonies, form of prayer and services used in Westminster-Abby at the coronation of King James the First... with the coronation of King Charles the First in Scotland (London, 1685), p. 19-20.

${ }^{67} \operatorname{RPS} 1640 / 6 / 36$ 'The act of the general assembly ordaining by ecclesiastical authority the subscription of the faith and covenant', 6 June 1640; RPS 1584/5/9 'Concerning the authority of the three estates of parliament', 22 May 1584.

${ }^{68}$ RPS $1425 / 3 / 6$ 'Of leagues and bonds not to be made', 12 March 1425; 'The lawfulnes of the subscriptione to the confessione of faith' in Rothes, Relation of Proceedings, p. 90.

${ }^{69}$ Ford, Lawful Bonds, p. 57.
} 
royal control of parliament by reforming the Lords of the Articles and an act requiring parliamentary consent for royal appointments to state office. ${ }^{70}$ Though these reforms can be seen as striking innovations, an order of 1640 justified them as a return to Scotland's historic constitution, 'agreeable to the fundamental laws and customs' of the realm. The order required the swearing of yet another oath by which this constitutional framework would be accepted by all subjects. ${ }^{71}$ A further step was taken in 1643 with the negotiation of the Solemn League and Covenant with the English parliament. Representing a military alliance and reformed confessional association, this second covenant envisioned a confederal union of the three kingdoms with separate but similarly reformed churches in Scotland, England and Ireland. ${ }^{72}$

From 1639, every subject in the land, from members of parliament and office-holders in church and state to ordinary men and women in local parishes, was required to swear the National Covenant by an order of Privy Council, later ratified by the 1640 Parliament; and from 1643 all subjects were required to swear the Solemn League. ${ }^{73}$ This bound the subjects to support the constitutional vision spelled out by the covenants by endorsing its principles and promising to maintain the realm and church as defined by law. ${ }^{74}$ Edward Vallance has stressed the importance of mass subscription to devices like the National Covenant as a 'prime means' of 'confirming the new constitution' envisioned by such documents. ${ }^{75}$ While records of local subscription are incomplete,

\footnotetext{
${ }^{70} \operatorname{RPS} 1640 / 6 / 5$ 'Act 2 Act anent the constitution of this parliament and all subsequent parliamentis', 2 June 1640; RPS 1640/6/37 'Act 19 Regarding the ratification of the acts of the assembly', 6 June 1640; RPS 1640/6/38 'Act 20 Act rescissory', 6 June 1640; RPS 1640/6/27 'Act 12 Act statutory appointing parliaments to be held once every three years', 6 June 1640; RPS 1641/8/55 'Act regarding the election of the officers of state, councillors and sessioners', 16 Sept 1641; Young, The Scottish Parliament, pp. 20-24, 29-42; Macinnes, British Revolution, pp. 128, 141.

${ }^{71} R P S 1640 / 6 / 61$, 'Act 43 Ordaining the whole subjects and lieges of this kingdom to obey, maintain and defend the conclusions, acts and constitutions of this present session of parliament, and to subscribe the bond appointed for that effect', 10 June 1640.

${ }_{72} \operatorname{RPS} 1643 / 6 / 75$, 'Covenant to be betuix the two kingdomes', 17 August 1643; D. Stevenson, 'The early Covenanters and the federal union of Britain' in R. Mason, ed., Scotland and England 1286-1815 (Edinburgh, 1987), pp. 163-181; Macinnes, British Revolution, p. 150.

${ }^{73} \operatorname{RPS} 1640 / 6 / 33$ 'Act 18 Act anent the ratification of the covenant', 6 June 1640; RPS 1640/6/36 'The act of the general assembly ordaining by ecclesiastical authority the subscription of the faith and covenant', 6 June 1640; RPS 1640/6/35, 'The act of his majesty's most honourable privy council, at Edinburgh, 30 August 1639, containing the answer of the supplication above-written', 6 June 1640;1643/6/76, 'The estates' approbation of the covenant', 17 Aug. 1643.

${ }^{74}$ On the terms of state oaths, see A. Raffe, 'Scottish state oaths and the Revolution of 1688-90', in Scotland in the Age of Two Revolutions, pp. 177-5.

${ }^{75}$ Vallance, 'Oaths, Covenants', p. 29.
} 
surviving evidence shows that the National Covenant was renewed in 1643 alongside the Solemn League and Covenant and sworn again in 1648 in response to the Engagement. ${ }^{76}$

The Covenanters also sought to use the coronation oath to bind the monarch to their constitutional programme. While late medieval Scottish coronations suggested an implicit contract between king and people, the Covenanters made this explicit. ${ }^{77}$ In his Dialogue, Buchanan had argued that the coronation oath made a mutual compact in which the people agreed to obey and the king agreed to rule by law. ${ }^{78}$ The National Covenant stated that the 1633 coronation oath sworn by Charles I compelled him to maintain standing law in favour of the church by his promise to rule 'according to the laws, constitutions and customs of this your kingdom'.${ }^{79}$ When Charles declined to agree with this interpretation, the regime attempted to force his son to accept these terms through his swearing of the covenants and his subsequent coronation oath. The 1649 General Assembly demanded a covenanted coronation, asserting that 'a boundles and illimited power is to be acknowledged in no king nor magistrate' and, that regardless of any hereditary right to the crown, the young Charles would not be 'admitted to the exercise of his power' unless 'by and attour the oath of coronation', he would accept the covenants and presbyterian church government as established by the Scottish parliament. ${ }^{80}$ This echoed a doctrine of contractual monarchy articulated by 'noblemen, barrons and uthers' at the July 1567 General Assembly. Future princes, they stated, 'befor they be crownit and inaugurat', 'sall make ther faithfull league and promise' to maintain 'the true religioun of Jesus Chryst presentlie confessit and establishit within this realme', with a 'band and contract to be mutuall and reciproque in all tymes comeing betuixt the prince and God, and also betuixt the prince and faithfull peiple. ${ }^{81}$ The Scottish parliament in 1650 demanded that the young Charles Stuart indicate his concurrence with the

\footnotetext{
${ }^{76}$ J. McDougall, 'The Reception of the 1643 Solemn League and Covenant', unpublished MLitt dissertation, University of Glasgow (2014), pp. 45-46, 49.

${ }^{77}$ A. Thomas, 'Crown imperial: coronation ritual and regalia in the reign of James V' in J. Goodare and A. R. MacDonald (eds), Sixteenth-Century Scotland (Leiden, 2008), p. 51.

${ }^{78}$ Mason, 'People power?', 172; A. Mann, 'Parliaments, princes and presses: voices of tradition and protest in early modern Scotland' in U. Boker and J. A. Hibbard (eds), Sites of Discourse-Public and Private SpheresLegal Culture (Amsterdam, 2002), pp. 79-91, at p. 81.

${ }^{79}$ RPS 1640/6/36 'The act of the general assembly ordaining by ecclesiastical authority the subscription of the faith and covenant', 6 June 1640; Ceremonies, p. 17; Lyall, 'Medieval Scottish coronation', pp. 15-16.

80 'A seasonable and necessary warning and declaration' in Acts of the General Assembly of the Church of Scotland 1638-1842 (Edinburgh, 1843), pp. 203-211, quotes at pp. 206, 208.

${ }^{81} \mathrm{~T}$. Thomson (ed.), Acts \& Proceedings of the General Assemblies of the Kirk of Scotland, 1560-1618 (Edinburgh,1839), pp. 109.
} 
covenants and the terms of the Scottish coronation oath before being allowed to enter Scotland and act as king. ${ }^{82}$

Charles subscribed both covenants before landing in Scotland late in June 1650, after which Lord Chancellor John Campbell, earl of Loudon advised him that 'Your Majesty is now obliged by the oath of Covenant with God and your people, to promote the ends of the Covenant in your royal station and place, to the utmost of your power' ${ }^{83}$ As Lord Chancellor, Loudoun commenced the January 1651 coronation ceremony with an invitation expressing the desire of the people that Charles take up his crown and maintain religion as defined by the covenants. In return, they offered their lives and fortunes in defence of religion, the king's person and his crown. ${ }^{84}$ This can be contrasted with the equivalent scene of the coronation orchestrated by Archbishop Laud in 1633 in which Charles I was beseeched to receive the people under his protection. ${ }^{85}$ In the kirk at Scone, the moderator of the Commission of the General Assembly, Robert Douglas, gave a sermon elucidating an Old Testament example of 'a Covenant between the LORD, and the King, and the People'. ${ }^{86}$ Kings had no 'arbitrary and unlimited Power', he stated; instead, Charles 'receiveth this Day a Power to govern: but a Power limited by Contract' and 'Conditions' to which 'he is bound by Oath'. ${ }^{87}$ This was followed by Charles' renewal of the Covenants and a promise, 'for my self and successors', to accept future acts of parliament in support of presbyterian government. ${ }^{88}$ After the ritual of popular acclamation, Charles swore the 1567 coronation oath by which he promised to rule 'according to the loveable Laws, and Constitutions received in this Realm, ${ }^{89}$ The people's oath in 1651 used a form of the wording of the

\footnotetext{
${ }^{82}$ RPS 1650/3/12, 'Instructions from the parliament to the commissioners going to the king's majesty', 8 March 1650 .

${ }^{83}$ Earl of Loudoun to Charles II, Aug. 1650 in S. R. Gardiner (ed.), Letters and Papers Illustrating the Relations between Charles the Second and Scotland in 1650 (Edinburgh, 1894), p. 131.

${ }^{84}$ The Form and Order of the Coronation of Charles II (Aberdeen, 1651), sig. A2. See also J. Crichton-Stuart, Scottish Coronations (Paisley, 1902), pp. 141-209.

${ }^{85}$ The Ceremony, Form of Prayer and Services ... with the Coronation of King Charles I in Scotland (London, 1685), 16; Scottish Coronations, pp. 86-87.

${ }^{86}$ King Joash, 2 Kings 11, v. 12, 17.

${ }^{87}$ Form and Order, pp. 5-40; Scottish Coronations, pp. 6-51.

${ }^{88}$ Form and Order, p. 41; Scottish Coronations, pp. 53-54.

${ }^{89}$ Form and Order, p. 42-43; Scottish Coronations, pp. 54-56; RPS A1567/12/7 'Concerning the king's oath to be given at his coronation', [Dec. 1567].
} 
nobles' oath in 1633 by which they swore loyalty and allegiance as 'liege-men'.$^{90}$ Inserted into every oath in 1651 were clauses making all parties subject to the covenants.

The contractual and conditional monarchy envisioned by the regime in 1651 did not survive Cromwell's conquest or the restoration of Charles II on firmly royalist grounds. Keith Brown has suggested that post-Reformation royalism had less to do with 'ideas about absolutism' than a wish to 'promote peace and stability'. ${ }^{91}$ David Stevenson has noted the weak appeal of strict Bodinian absolutism amongst royalist nobles in the early 1640s, but Clare Jackson has observed a greater appetite for divine right royalism after the disorders of the Covenanting era. ${ }^{92}$ By 1689 , a pamphleteer could observe that the idea that kings derived their authority directly from God had taken 'deep root ${ }^{93}$ Restoration royalism affirmed the unlimited authority of the ancient Scottish monarchy, based on original rather than recent constitutions, and demanded the unlimited allegiance of the subject. After being required to swear a new oath of parliament acknowledging the king's unconditional authority, the Scottish estates in 1661 passed acts restoring royal powers to choose officers and convene meetings of parliament and reinstating the Lords of the Articles. ${ }^{94}$ A new oath of allegiance required office-holders to indicate their acceptance of these acts. ${ }^{95}$ This was capped with an act recissory annulling the Covenanters' constitutional programme by disqualifying all legislation passed after $1633 .^{96}$ This was justified by 'the sacred right inherent to the imperial crown (which his majesty holds immediately from God Almighty alone) and by the ancient constitution and fundamental laws of the kingdom'. ${ }^{97}$ The conditional terms of the covenanted oaths sworn by king and people in 1651 were refuted in an act of 1662 asserting the royal supremacy over the church. This stated that 'the

\footnotetext{
${ }^{90}$ Form and Order, pp. 44-45; Ceremony, Form of Prayer and Services, p. 20.

${ }^{91}$ K. Brown, Noble Power in Scotland from the Reformation to the Revolution (Edinburgh, 2011), 209-10.

92 D. Stevenson, The 'Letter on Sovereign Power' and the Influence of Jean Bodin on Political Thought in Scotland', Scottish Historical Review 61:171, 1 (April 1982), pp. 25-43; Jackson, Restoration Scotland, pp. 5358 .

${ }^{93}$ Allegiance and Prerogative Considered ([Edinburgh?], 1689), p. 9.

${ }^{94}$ RPS 1661/1/7, 'Act for [William Cunningham, earl of Glencairn], the chancellor, to be president in parliament', 1 January 1661, 1661/1/16, 'Act asserting his majesty's prerogative in the choice of his officers etc.', 11 January 1661; 1661/1/17, Act for his majesty's prerogative in making of laws', 11 January 1661; $1661 / 1 / 13$, 'Commission to the lords of the articles and processes', 8 January 1661; MacIntosh, Scottish Parliament, pp. 19-21.

${ }^{95}$ RPS 1661/1/88, 'Act for taking the oath of allegiance and asserting the royal prerogative', 27 February 1661.

${ }^{96}$ MacIntosh, Scottish Parliament, pp. 23-25.

${ }^{97}$ RPS 1661/1/158, 'Act rescinding and annulling the pretended parliaments in the years 1640, 1641 etc.', 28 March 1661.
} 
ordering and disposall of the externall government and policie of the church doth propperlie belong unto his majestie as ane inherent right of the croun' ${ }^{98}$ In his 1684 Jus Regium, Lord Advocate Sir George Mackenzie of Rosehaugh reinvented Fergus I as an aboriginal absolutist to whom unconditional loyalty was owed. ${ }^{99}$ Similarly, a 1685 declaration by the Scottish parliament to James VII celebrated the 'solid, absolute authority' of the Scottish kings 'wherwith they were invested by the first and fundamentall law' of their ancient monarchy. ${ }^{100}$ Earlier, Sir John Nisbet of Dirleton, Lord Advocate under Charles II, had rejected the idea that 'what is required and promised, by the King at the time of his Coronation' were 'Conditiones Regni'. ${ }^{101}$ As Alasdair Raffe has emphasised, the estates recognised the legitimacy of James VII at his accession in 1685 even though he had not sworn the coronation oath, confirming the royalist view that neither the religious ceremony of coronation nor the coronation oath was necessary for the exercise of authority in a hereditary monarchy. ${ }^{102}$

Hardline Presbyterian dissenters responded to the Restoration regime in constitutionalist terms. In his Jus Populi Vindicatum of 1669, the future Lord Advocate James Steuart of Goodtrees defended violent popular resistance on the grounds that Charles II had been accepted as king by the people at his coronation under specific conditions spelled out in the covenants-what Steuart called a 'constitution by compact'. ${ }^{103}$ As the king had broken his compact, the people were justified in taking up arms. A paper seized in Queensferry in 1679, known as the 'New Covenant', expressed the view that the original covenant 'being the Coronation compact', the people's sworn allegiance to Charles II could be repudiated. ${ }^{104}$ The 1680 Sanquhar Declaration disowned Charles Stuart as having 'forfeited' the crown by his 'Perjury and Breach of Covenant' and his 'Tyranny and Breach of the very leges

\footnotetext{
${ }^{98}$ RPS $1662 / 5 / 9$, 'Act for the restitution and reestablishment of the ancient government of the church by archbishops and bishops', 27 May 1662.

${ }_{99}$ G. Mackenzie of Rosehaugh, Jus Regium (Edinburgh, 1684), p. 27.

${ }^{100}$ RPS 1685/4/16 'A declaration and offer of duty by the kingdom of Scotland, with an annexation of the excise to the crown', 28 April 1685. See also Jackson, Restoration Scotland, pp. 54-6.

${ }^{101}$ J. Nisbet of Dirleton, Some Doubts and Questions, in the Law, Especially of Scotland (Edinburgh, 1698), p. 132.

${ }^{102}$ Raffe, 'Scottish state oaths', p. 177.

103 [J. Steuart of Goodtrees], Jus Populi Vindicatum (1669), pp. 95-111, 118.

104 'The Queensferry Covenant' in R. Wodrow, The History of the Sufferings of the Church of Scotland, 2 vols, (Edinburgh, 1721-22), II, Appendix, p. 45.
} 
regnandi in Matters Civil'. ${ }^{105}$ Declared 'most treasonable and unparalleled' by the Privy Council, these views triggered a judicial pursuit of adherents. ${ }^{106}$

The Revolution of 1688-89 presented an opportunity to use an accession oath coupled with a 'claim of right' to produce a conditional monarchy. A presbyterian-dominated Convention orchestrated what seems to have been intended as a conditional offer of the Scottish crown to William of Orange and Mary Stuart. ${ }^{107}$ In contrast to England where the presentation of the Declaration of Right was less overtly tied to the offer of the crown, a proclamation by the Convention stressed that they had included an 'instrument of government', the 1689 Claim of Right, with the offer of the crown to William and Mary. ${ }^{108}$ The Claim of Right declared James VII to have 'forfaulted the right to the croune' because he had failed to take the coronation oath 'whereby the king, at his access to government, is obliged ... to rule the people according to the laudable laws.' In acting as king, James had 'invade[d] the fundamental constitution of this kingdom', changing it 'from a legal limited monarchy, to an arbitrary despotic power'. The Claim of Right declared a long list of monarchical practices to be unlawful and demanded substantial constitutional reforms, including the abolition of prelacy, regular meetings of parliament and the right to petition the king for relief of grievances. ${ }^{109}$ As Tim Harris has pointed out, the Claim of Right may have echoed the form of the English Declaration of Rights, but it went beyond its English precursor in demanding an overhaul of the constitution of the Scottish realm and national church. ${ }^{110}$ Accompanying the Declaration were the "Articles of Grievances to bee redressed in parliament' proposing additional judicial and constitutional reforms.

\footnotetext{
105 'The Sanquhar Declaration' in Ibid., p. 47.

${ }^{106}$ P. Hume Brown (ed.), Register of the Privy Council of Scotland, series 3, vol. 6 (1678-1680), (Edinburgh, 1914), pp. 480-5.

${ }^{107}$ On the election of a Presbyterian majority, see D. J. Patrick, 'Unconventional procedure: Scottish electoral politics after the Revolution' in Brown and Mann (eds), Parliament and Politics in Scotland, pp. 208-244.

James Halliday, Alan Macdonald and Alastair Mann view the crown as having been offered with conditions. J. Halliday, 'The Club and the Revolution in Scotland 1689-90', Scottish Historical Review 45, 140, part 2 (Oct. 1966), p. 145; A. Macdonald, 'Statehood, nationhood and treason in early modern Scotland' in L. Eriksonas and L. Müller (eds), Statehood Before and Beyond Ethnicity: Minor States in Northern and Eastern Europe, 16002000 (Brussels, 2005), pp. 85-108 at 105; A. Mann, 'Inglorious revolution', p. 127.

${ }^{108}$ Harris, 'The People, the Law, and the Constitution', p. 46; H. Nenner, 'Constitutional uncertainty and the Declaration of Rights' in B. C. Malament (ed.), After the Reformation (Manchester, 1980), p. 297; RPS 1689/3/109, 'Proclamation declaring the king and queen of England to be king and queen of Scotland', 11 April 1689.

${ }^{109}$ RPS 1689/3/108, 'Declaration of the estates containing the Claim of Right and the offer of the crown to the king and queen of England', 11 April 1689.

${ }^{110}$ Harris, 'The People, the Law, and the Constitution', pp. 46-53.
} 
These objected to measures that were lawful but considered by the revolutionaries to be unjust, such as the Lords of the Articles committee by which the king managed parliament. The Grievances asked the king to redress these concerns with new laws. ${ }^{111}$

These documents were sent to London with instructions directing a set of commissioners to read both the Claim of Right and Articles of Grievance before administering the 1567 coronation oath. ${ }^{112}$ In a letter to William and Mary, the Convention stated that they would take the swearing of the oath as 'testimony of your majestie and the queen's acceptance' of the crown and, by implication, its accompanying terms. ${ }^{113}$ The importance of the order of presentation is indicated by a subsequent uproar in parliament over an allegation that the commissioner for the royal burghs, Sir John Dalrymple of Stair, had attempted to hold back the Grievances until after the oath. ${ }^{114}$ An act recognising the authority of the royal couple noted that William and Mary had sworn 'the oath appointed by law to be taken by all kings and queens of this realm before they exercise their regal power' and that the crown had been offered with the Claim of Right. ${ }^{115}$ This did not include a more explicit statement that the monarchs had accepted the instrument of government proposed by the constitutionalist leader Sir James Montgomery of Skelmorlie, but parliament cultivated awareness of the terms of the accession by ordering the printing of the coronation oath, Claim of Right and Articles of Grievances. ${ }^{116}$ By 1690 , demands pressed by Montgomery of Skelmorlie and a constitutionalist 'Club' for the fulfillment of these terms led to acts abolishing prelacy and the Lords of the Articles committee. ${ }^{117}$

\footnotetext{
${ }^{111}$ RPS 1689/3/121, 'The Articles of Grievances', 13 April 1689; RPS 1689/3/161, 'Two articles added to the grievances', 24 April 1689.

${ }_{112} R P S 1689 / 3 / 168$ 'Instructions to [the] e[arl of] Argyle, [Sir James Montgomery of] Skelmorlie and Sir John Dalrymple [of Stair]', 25 April 1689; RPS 1689/3/131, 'The oath to be administered to the king and queene at their acceptance of the croune', 18 April 1689. The language of the 1567 oath was Anglicised in 1689 but otherwise was essentially the same.

${ }^{113} \operatorname{RPS} 1689 / 3 / 159$, 'Letter from the estates to the king's majestie', 24 April 1689.

${ }^{114}$ Halliday, 'The Club', pp. 150-51.

${ }^{115} R P S$ 1689/6/11, 'Act recognising their majesties' royal authority', 17 June 1689.

${ }^{116}$ Halliday, 'The Club', p. 149; RPS 1689/6/17 'Warrant for printing the instrument of government', 21 June 1689. See also The Solemn Oath which the Kings of Scotland Are to Take, by Virtue of an Act of Parliament...Anno 1567 (1689).

${ }^{117}$ RPS 1689/6/36, 'Act abolishing prelacy', 22 July 1690; RPS 1690/4/22, 'Act concerning the election of committees of parliament', 8 May 1690; Halliday, 'The Club', pp. 152-54; Mann, 'Inglorious revolution', p. 129.
} 
For supporters of the Revolution, the coupling of the Claim of Right with the accession oath had created an explicit contract between king and people. In a paper designed to assure extreme presbyterians that they could accept William and Mary as legitimate rulers, the cleric Alexander Shields expressed his understanding that the Claim of Right represented a 'compact', 'on which terms and stipulations the King and Queen accept[ed] the crown' with their oath. Though the full coronation ceremony with the people's traditional acclamation and oath had not been performed, Shields argued that the monarchs' swearing of the oath created 'ane obligation of alleadgement' from the people and 'of right administration' on the monarchs' part. Moreover, even though the 1638 and 1643 covenants had not been renewed, Shields felt that William and Mary had agreed to support the 'national covenant' understood to be embodied in the Scottish reformed church. Shields referred to the warning of the 1649 General Assembly against a 'boundless and illimited power' and affirmed that, unlike the 'late tyrant' James VII, 'this Kings power is limited by preliminary provisions'. ${ }^{118}$

After 1689, the Claim of Right was cited as a fundamental constitutional document. A 1696 act to regulate the succession stipulated that William's successor must accept the crown under the terms laid down by the Claim of Right. ${ }^{119}$ An attempt by William in 1699 to stop a petitioning campaign organised by supporters of the Company of Scotland was seen as an abrogation of the right to petition secured by the Claim of Right. A substantial proportion of the Privy Council voted against a royal proclamation designed to suppress petitioning, the right to petition according to the Claim of Right was defended in a manuscript tract and Country party leaders defied the proclamation to collect a reported 21,000 signatures on a national petition calling for a meeting of Parliament. ${ }^{120}$ Following Anne's accession in 1702, Parliament confirmed that the queen had taken the Scottish 'coronation oath conforming to the said Claim of Right' ${ }^{121}$ When Anne indicated sympathy for the toleration of episcopalian worship in 1703, presbyterian pamphleteers cited the Claim of Right as a constitutional

\footnotetext{
${ }^{118}$ National Library of Scotland, Wodrow Quarto xvi, item 3, Alexander Shields, 'To Sir R[obert] H[amilton] the answer of his protestation', ff. 99-113 at 102v-103v.

${ }^{119}$ RPS 1696/9/135, 'Act for the security of the kingdom', 9 Oct. 1696.

${ }^{120}$ K. Bowie, Scottish Public Opinion and the Anglo-Scottish Union (Woodbridge, 2007), pp. 58-59; J. Young, 'The Scottish Parliament and the politics of empire: Parliament and the Darien project, 1695-1707', Parliaments, Estates and Representation 27,1 pp. 181-4.

${ }^{121}$ RPS 1702/6/28, ‘Act recognising her majesty's royal authority', 9 June 1702. Though James VII, William and Mary and Anne did not perform the traditional Scottish coronation ceremony, contemporaries still referred to the oath they took at their accession as a 'coronation oath'.
} 
barrier to any act of toleration. Fearing a Jacobite revival under Anne, writers warned against any undermining of the Claim of Right and its article on prelacy. Scottish episcopalians in turn made great efforts to attack the Claim of Right. Far from being a fundamental limitation, it was argued, the Claim of Right was a mere statute which could be overturned by a new law. ${ }^{122}$ In response, a presbyterian majority in the 1703 parliamentary session passed an act making it 'high treason' for any subject to 'quarrell, impugne or endeavour by writeing, malicious and advised speaking, or other open act or deed, to alter or innovat the Claim of Right or any article thereof' ${ }^{123}$ In the union debates of 1706-07, the Claim of Right was cited again in defense of the right to petition parliament and was treated as a foundation stone of the Scottish presbyterian church and realm. ${ }^{124}$ For the inhabitants of the burgh of Ayr, the Claim of Right gave them a 'priviledge of petitioning', especially regarding 'so great a concern as that of ane union with England'. ${ }^{125}$ St. Andrews asked for the rejection of any articles of union that might 'Contradict The Claim of Right'. ${ }^{126}$

Limitations came to the fore again in 1703-04 after the death of Queen Anne's only surviving child led the English parliament to pass the 1701 Act of Settlement naming Sophia, electress of Hanover and Protestant grand-daughter of James VI and I, as the successor to the English throne. Titled 'An Act for the further Limitation of the Crown and better securing the Rights and Liberties of the Subject', this reforming legislation required that the successor be Protestant and take the English coronation oath. It also demanded the consent of the English parliament for the pursuit of war on behalf of foreign territories. ${ }^{127}$ This restricted a primary mark of sovereignty, the power to wage war, in order to regulate English involvement in continental wars arising from the monarch's Hanoverian interests. The act offered an obvious model for an attempt to impose limitations on the successor to the Scottish crown. The hostility of the English parliament and English crown agents towards the Company of Scotland, combined with a significant loss of Scottish trade through the Nine Years War

\footnotetext{
${ }^{122}$ Bowie, Scottish Public Opinion, pp. 36-39; [George Brown], Toleration defended (n.p., 1703), pp. 7-8.

${ }^{123} \operatorname{RPS} 1703 / 5 / 190$, 'Act ratifieing the turning the meeting of the estates in the year 1689 into a parliament', 16 Sept. 1703.

${ }^{124}$ J. Hamilton, The Lord Beilhaven's Speech in Parliament ([Edinburgh], 1706), p. 3.

${ }^{125}$ National Records of Scotland (hereafter NRS), Supplementary Parliamentary Papers PA7/28/25, address of the burgh of Ayr.

${ }^{126}$ NRS Supplementary Parliamentary Papers PA 7/28/47, address of the burgh of St. Andrews.

127 'Act of Settlement [1701]', www.legislation.gov.uk, accessed 13 Jan. 2014.
} 
with France (1689-97), had led to angry demands for reform of the regal union by $1700 .{ }^{128}$ Unilateral reform could be achieved through limitations on Anne's successor in Scotland.

After the failure of union negotiations in 1702-03, a new Scottish parliament considered the question of the succession from 1703. An 'Act for the Security of the Kingdom' was passed in the 1703 and 1704 parliamentary sessions by a Country opposition that now included a significant tranche of Jacobite Cavaliers. ${ }^{129}$ In outlining a process by which the Scottish parliament would name the next monarch after Anne's death, this required that the Claim of Right be read to the new monarch before the administration of the coronation oath. It went on to demand that, before the English monarch could be accepted in Scotland, 'conditions of government [be] settled and enacted as may secure the honour and sovereignty of this crown and kingdom, the freedom, frequency and power of parliaments, [and] the religion, liberty and trade of the nation from English or any foreign influence'. ${ }^{130}$ Usually understood in the historiography of the Union as an outburst of nationalist fervour, it is more helpful to see the Act of Security as the latest in a long line of constitutionalist responses to tensions in the Union of Crowns. ${ }^{131}$

Speaking as a shire commissioner, Andrew Fletcher of Saltoun provided a radical vision for 'conditions of government' by proposing the transfer of specific powers to the Edinburgh parliament, including the making of war and peace and the selection of officers of state. Ultimately, Fletcher envisioned a sovereign parliament with annual elections and an automatic royal assent for its acts. ${ }^{132}$ The earl of Marchmont proposed a more modest set of limitations in a draft act for the Hanoverian

\footnotetext{
${ }^{128}$ D. Watt, The Price of Scotland: Darien, Union and the Wealth of Nations (Edinburgh, 2007), pp. 36-45, 97103; Young, 'The Scottish Parliament and the politics of empire', pp. 181-4; C. Whatley, 'Taking stock: Scotland at the end of the seventeenth century' in T. C. Smout (ed.), Anglo-Scottish Relations from 1603 to 1900, (Cambridge, 2005), pp. 115-116.

${ }^{129}$ On the election, see K. Brown, 'Party politics and parliament: Scotland's last election and its aftermath, 1702-3' in Brown and Mann (eds), Parliament and Politics, 245-86.

${ }^{130} \operatorname{RPS} 1704 / 7 / 68$, 'Act for the security of the kingdom', 5 August 1704 . This quote from the 1704 act omits an additional demand made in 1703 for a communication of trade with England. K. Bowie, 'Publicity, parties and patronage: parliamentary management and the ratification of the Anglo-Scottish union', Scottish Historical Review 87, supplement (2008), p. 86.

${ }^{131}$ Young describes the sessions of 1703-4 as exhibiting 'constitutional nationalism' . Young, 'The Scottish Parliament and the politics of empire', p. 186; J.R. Young, 'The parliamentary incorporating union of 1707: political management, anti-unionism and foreign policy' in T. M. Devine and J. R. Young (eds), Eighteenth Century Scotland: New Perspectives (East Linton, 1999), pp. 25-26.

${ }^{132}$ Fletcher, Political Works, pp. 132, 138-39.
} 
succession in $1703 .{ }^{133}$ Marchmont's overture focused on biennial parliamentary meetings adjourned with the consent of the assembly and parliamentary approval for the appointment of crown officers.

The successor was to be bound by these conditions and the Claim of Right. ${ }^{134}$ In 1703, one limitation was made into law with the 'Act anent Peace and War'. ${ }^{135}$ Requiring parliamentary approval of all declarations of war and treaties of peace, this went well beyond the limitation found in the English Act of Settlement, reflecting not fears of a German monarch's continental commitments but grievances arising from British wars with France, one of Scotland's primary trading partners. ${ }^{136}$ The Jacobite shire commissioner George Lockhart of Carnwath felt that the act was 'absolutely necessary considering how much the nation had lost by being brought into England's wars. ${ }^{137}$ In constitutional terms, the act responded to Queen Anne's use of the royal prerogative to involve her Scottish realm in the War of the Spanish Succession (1702-1714). ${ }^{138}$

Both Fletcher and the presbyterian pamphleteer George Ridpath argued for reform as a restoration of pre-1603 laws and practice. In a speech to parliament, Fletcher accused the English of aiding the Stuarts in the subversion of the Scottish constitution: 'when our Kings succeeded to the Crown of England, the Ministers of that Nation took a short way to ruin us, by concurring with their Inclinations to extend the Prerogative in Scotland'. ${ }^{139}$ In his 1703 Historical Account of the Antient Rights and Power of the Parliament of Scotland, Ridpath asserted that 'before the Union of Crowns', the Parliament 'had a commanding Share in all the Rights of Sovereignty'. ${ }^{140}$ He mined the 1566 edition of Actis and Constitutiounis of the Realme of Scotland for evidence that parliamentary approval had been required for the declaration of war and raising of troops. ${ }^{141}$ Ridpath and Fletcher also accused recent governments of airbrushing the past. Fletcher alleged that 'in the last two editions

\footnotetext{
${ }^{133}$ D. Szechi, Britain's Lost Revolution? Jacobite Scotland and French Grand Strategy, 1701 -8 (Manchester, 2015), pp. 122-123; Lockhart, 'Scotland's Ruine', p. 39.

${ }^{134}$ [Patrick Hume, earl of Marchmont], Overture by Way of Act Concerning the Succession ([Edinburgh], 1703). 135 RPS 1703/5/193, 'Act anent peace and war', 16 Sept 1703.

${ }^{136}$ S. Talbott, Conflict, Commerce and Franco-Scottish Relations, 1560-1713 (London, 2014); Whatley, 'Taking stock', pp. 115-116.

${ }^{137}$ G. Lockhart of Carnwath, 'Scotland's Ruine': Lockhart of Carnwath's Memoirs of the Union, ed. D. Szechi (Aberdeen, 1995), p. 37.

${ }^{138}$ C. A. Whatley, The Scots and the Union (Edinburgh, 2006), p. 195.

${ }^{139}$ A. Fletcher, Speeches by a member of the Parliament which began in at Edinburgh the $6^{\text {th }}$ of May 1703 ([Edinburgh], 1703), p. 6.

${ }^{140} \mathrm{G}$. Ridpath, Historical account of the antient rights and power of the Parliament of Scotland ([Edinburgh?], 1703), p. vii.

${ }^{141}$ For example, Historical account, pp. 75-76.
} 
of our acts of parliament the most considerable laws for the liberty of the subject are industriously and designedly left out'. ${ }^{142}$ Ridpath identified these editions as the Laws and Acts of Parliament, produced by Sir Thomas Murray in multiple editions from 1681 to $1685 .{ }^{143}$ In Ridpath's view, two concepts of the historic constitution of the realm, royalist and constitutionalist, were competing for primacy in Scottish political memory and culture. In his Historical Account, he sought to challenge what he saw as a new and illegitimate royalism, noting that his view of the past would 'sound but oddly amongst some of our young Sparks, Asserters of Prerogative. ${ }^{144}$

Though Anne approved a version of the Act of Security in 1704 in return for taxation, she was not willing to concede sufficient reforms to secure an act for the Hanoverian succession in Scotland. ${ }^{145}$ The royal assent was refused to two reforming acts passed in 1704, for triennial parliaments and parliamentary consent for state officers. ${ }^{146}$ From 1705, Anne and her ministers returned to incorporating union as a means to resolve the problem of the succession. In Scotland, there was much opposition to incorporation but, as John Robertson has shown, Scottish unionists saw advantages in joining a more powerful parliament in London instead of maintaining a separate parliament vulnerable to English control through the prerogative powers of the monarch. ${ }^{147}$ Presbyterians unionists nevertheless sought to use the British coronation oath to maintain the church as defined in Scots law and the Claim of Right. On 8 November 1706, the Commission of the General Assembly sent an address to the Scottish parliament asking that any new British monarch promise to 'maintain the Doctrine, Worship, Discipline and Government of this Church and the Rights \& privileges thereof as now by law Established ${ }^{148}$ In response, an act of the Scottish parliament asserted that, as a condition of union, Anne's successors must at their accession 'swear and subscribe that they shall inviolably maintain and preserve the foresaid settlement of the true Protestant religion

\footnotetext{
${ }^{142}$ Fletcher, Political Works, p. 132.

${ }^{143}$ Ridpath, Historical account, pp. xvii-xviii.

${ }^{144}$ Ridpath, Historical account, p. 75.

145 Allan Macinnes has argued that Anne did not wish to allow the Scottish parliament to emulate claims for autonomy, backed up by assertions of a right to resist by force of arms (rokosz), made by Polish nobles in the Commonwealth of Poland-Lithuania. Macinnes, Union and Empire, pp. 267-68.

${ }^{146}$ Young, 'Scottish parliament and the Covenanting heritage', p. 249.

${ }^{147}$ J. Robertson, 'An elusive sovereignty: the course of the union debate in Scotland 1698-1707', in J. Robertson (ed.), A Union for Empire (Cambridge, 1995), pp. 198-227.

${ }^{148}$ NRS Supplementary Parliamentary Papers, PA 7/20/19, 'Humble Representation and Petition of the Commission of the General Assembly', 8 November 1706.
} 
with the government, worship, discipline, right and privileges of this church as above established by the laws of this kingdom, in prosecution of the Claim of Right'. ${ }^{149}$ This has been recognised as a contribution of the 1689 Revolution in Scotland to the development of contractual monarchy in Britain, a contribution made possible by a long series of attempts to use the coronation oath to impose conditions on post-Reformation Scottish monarchs. ${ }^{150}$

At the same time as presbyterian unionists sought to limit a new British monarch, royalist unionists argued for the unlimited sovereignty of the Scottish king in parliament in order to justify the ratification of the union treaty. George Mackenzie of Rosehaugh had opposed proposals made in 1669-70 for incorporating union by arguing that the Scottish parliament did not have the power to alienate rights of government and representation associated with property held by tenants-in-chief to the king. ${ }^{151}$ This was echoed later in more populist terms by presbyterian pamphleteers who insisted that the direct consent of freeholders was required to alter the constitution of the realm. ${ }^{152}$ These writers edged towards a notion of popular sovereignty in order to deny the legitimacy of legislation for union. James Hodges argued in 1703 that 'no Government nor Governours ... of a Free People have, or can claim any Just Power to dispose of the fundamental Rights and Liberties of the People, whom they Govern'. ${ }^{153}$ In 1706, he demanded an assembly of freeholders, male and female, to vote on the treaty. ${ }^{154}$ In response, Mackenzie's nephew, the royalist George Mackenzie, earl of Cromarty, did not hesitate to argue for the sovereignty of the Scottish monarch in his head court of parliament and the unlimited power of parliamentary representatives to change fundamental laws. ${ }^{155}$ The making of

\footnotetext{
${ }^{149}$ RPS 1706/10/251, 'Act for securing of the Protestant religion and presbyterian church government', 16 Jan 1707.

${ }^{150}$ Raffe, 'Scottish state oaths', p. 179.

${ }^{151}$ G. Mackenzie, 'Parliament XVII', in The works of that eminent and learned lawyer, Sir George Mackenzie of Rosehaugh, vol. I, (Edinburgh, 1716), pp. 359-361. See also G. Mackenzie, A discourse concerning the three unions between Scotland and England, (Edinburgh, 1714), pp. 110, 141, 143.

${ }^{152}$ [R. Wylie], A letter concerning the union, with Sir George Mackenzie's observations and Sir John Nisbet's opinion upon the same subject ([Edinburgh], 1706); [G. Ridpath], Considerations upon the union (London, 1706).

${ }^{153}$ [J. Hodges], The rights and interests of the two British monarchies, inquir'd into, and clear'd (London, 1703), pp. 40-41.

${ }^{154}$ [J. Hodges], The rights and interests of the two British monarchies, with a special respect to an united or separate state (London, 1706), pp. 69-74.

${ }^{155}$ [G. Mackenzie, earl of Cromarty], A friendly return to a letter concerning Sir George Mackenzie and Sir John Nisbet's observation and response, on the matter of the union ([Edinburgh],1706), second letter, p. 29. On this debate, see also Bowie, Scottish Public Opinion, pp. 94-5, 104; Jackson, 'Conceptions of Nationhood', pp. 71-74; Kidd, Union and Unionisms, pp. 87-93.
} 
the Union thus rested on an assertion of untrammelled monarchical sovereignty, overtaking a form of constitutionalism that sought to impose statutory conditions on the monarch, secured by oaths.

Though constitutionalism had served presbyterian interests in 1640-41 and 1689, episcopalian Jacobites turned to constitutionalism in order to restrict the powers of a restored Catholic monarch. The imposition of conditions on James VII had been a possible outcome of William's landing in 1688 and Sir James Montgomery of Skelmorlie returned to this with an abortive Jacobite plot late in 1689. ${ }^{156}$ Cavaliers supported the constitutionalist Country platform from 1703 to 1707 and earl Marischal William Keith protested for conditions of government on the successor as an alternative to incorporation in November 1706. ${ }^{157}$ As Daniel Szechi has shown, in 1705 Scottish Jacobite leaders drafted an 'instrument of government' for a restored Stuart monarchy that demanded triennial parliaments and parliamentary consent for state officers and foreign alliances. The terms of the monarchy were to be established by a Convention, as in 1689, and secured with a binding oath of allegiance from which the people were to be released if the king broke his conditions. Termed a 'Caledonian Commonwealth' by an English spy, Szechi has characterised this programme as 'the kind of constitutional monarchy that was not to be seen in the British Isles for another hundred years' ${ }^{158}$

The pursuit of conditions of government by royalist Jacobites indicates the importance of confessionalism to Scottish constitutionalism in this era. A primary purpose of limitations was to restrict the monarch's ability to alter the reformed church, especially after 1603 as crown management of national assemblies increased. Though 'two kingdoms' ecclesiology rejected erastian controls, the church embraced the legitimacy provided by parliamentary ratification. ${ }^{159}$ Constitutionalist objections to Charles I in 1637 centred on his use of the royal prerogative to introduce ecclesiastical changes. Once in power, the Covenanting regime attempted to use oaths to bind the people and the king to the defence of the reformed church as defined by standing law. Restoration royalists responded by asserting the unlimited supremacy of the monarch and demanding unlimited allegiance. The

\footnotetext{
${ }^{156} \mathrm{R}$. Beddard, 'The unexpected whig revolution of 1688 ' in R. Beddard (ed.), The Revolutions of 1688 (Oxford, 1991), pp. 12-18; Halliday, 'The Club', pp. 156; P. Hopkins, Glencoe and the End of the Highland War (Edinburgh, 1986), pp. 208-09, 211, 220-21

${ }^{157}$ RPS 1706/10/69, 'Protestation of [William Keith], earl Marischal and others', 15 Nov. 1706.

${ }^{158}$ Szechi, Britain's Lost Revolution?, pp. 130-138, quotes at 138.

${ }^{159}$ J. Stephen, 'Defending the Revolution: the Church of Scotland and the Parliament, 1689-95', Scottish Historical Review 89,1: 227 (April 2010), 19-53.
} 
Revolutioners of 1689 used the Claim of Right and the accession oath to reassert the principle of a 'legal limited monarchy' and set conditions on the offer of the crown leading to the elimination of prelacy and a reduction in the crown's ability to manage parliament. After the Revolution, fears for the national interest in the regal union led to calls for the statutory delegation of powers to the Scottish parliament. Presbyterian unionists turned to the British coronation oath to protect the established church after 1707 while Jacobites hoped limitations would facilitate the restoration of a Catholic monarch. Across the Union of Crowns era, special emphasis was placed on regular elections and meetings of parliament and parliamentary approbation of church government, crown officers and foreign policy. These forms of Scottish constitutionalism can seen as radical in their involvement of the people in explicit compacts with the king or the delegation of specific powers to parliament, in contrast to royalist ancient constitutionalism which emphasised the unconstrained power of the king. Nevertheless, this paper does not advance a claim for precocious modernity or offer comfort for a 'narrative of Scottish constitutional exceptionalism' stretching from the Declaration of Arbroath to modern written constitutions. ${ }^{160}$ Instead, it recognises the development across the century of thoroughly early modern tactics designed to secure national interests in a regal union by using covenants and coronation oaths to confirm the constitution of a limited monarchy and reformed church in parliamentary law.

${ }^{160}$ Mason, 'Beyond the Declaration of Arbroath', p. 267. 